Trinity College

Trinity College Digital Repository

Faculty Scholarship

Spring 2006

The Global War Against Teachers

Vijay Prashad

Trinity College, Vijay.Prashad@trincoll.edu

Follow this and additional works at: https://digitalrepository.trincoll.edu/facpub

Part of the Education Commons 


\title{
The Global War against Teachers
}

\author{
Vijay Prashad
}

David Horowitz has opened a new U.S. front in the Global War against Teachers $\left(\mathrm{GWOT}_{2}\right) .{ }^{1}$ After a long season of provocations at elite college campuses in 2000-2001 over the issue of reparations and slavery, Horowitz has now turned to the broader question of "intellectual diversity" on campuses. ${ }^{2}$ Horowitz, who turned from Marxist radical to McCarthyist radical in the space of the past three decades, and who is now president of the California-based Center for the Study of Popular Culture, has helped fashion an Academic Bill of Rights that is currently in Congress, and may soon enter the Colorado legislature. ${ }^{3}$ On the surface, the bill appears almost entirely unimpeachable. It calls on the academic community to protect the academic freedom of both teachers and students since this freedom is essential for the "central purposes of a University" - "the pursuit of truth, the discovery of new knowledge through scholarship and research, the study and reasoned criticism of intellectual and cultural traditions, the teaching and general development of students to help them become creative individuals and productive citizens of a pluralistic democracy, and the transmission of knowledge and learning to a society at large."

Who could disagree with these broad, even banal, goals? ${ }^{4}$ And if there is no disagreement with these goals, why is there this controversy? Because, contrary to Horowitz's stated goals, his approach, alongside the Congressional effort to "reform" area studies, intends to make the university into a pro-conservative and pro-Republican adjunct of the warfare state, or at least to thrash the Left into submission and to move the center to give the Right equal time even if its intellectual output is 
mediocre. ${ }^{5}$ The new imperialism has to confront the bastion of anti-imperialism within the knowledge factories. It has to dismantle the intellectual barracks and fortifications of that spawn of anticolonial movements before the hordes of the Right can with impunity churn out more and more soldiers for its global wars. Teachers are holding up the armies of the night. They have to be exorcised if the new imperialism is to move forward unabated.

\section{Overworked and Under Pressure to Stick to the Facts}

While the red and blue electoral map reveals an America that is almost evenly divided between Republicans and Democrats, in the nation's universities Republicans (and conservatives) have become almost as rare as unicorns. In most schools, Republicans are less well represented than Greens, Marxists and sects of the far left. This is an indefensible situation with far-reaching implications.

—David Horowitz, "The Problem with America’s Colleges and the Solution"

In mid-November 2003, I went to Brown University to give a talk on prisons for a class taught by Joy James. As is my habit, I stopped on the way to the lecture to browse through the campus paper - to get a flavor of the debates on hand. One advertisement, from Students for Academic Freedom, struck me. Its headline said it all: "Is Your Professor Using the Classroom as a Platform for Political Agendas? This Is a Violation of Your Academic Rights." 6 Then the advertisement offered this explication:

If you are not taking a course whose subject is the war in Iraq, your professor should not be making statements about the war in class. Or about George Bush, if the class is not on contemporary American presidents, presidential administrations or some similar subjects. We do not expect our doctors to impose their political opinions on us when we go to them for treatment. We should like-wise not be assaulted by the political prejudices of professors when we pay them for an education. ${ }^{7}$

A month before, I had accidentally sliced up my arm and had gone to my local hospital's emergency room. A towel worked as a tourniquet as I waited, and waited, and waited in a room filled with others who had equally terrible ailments. We waited, looked at each other, laughed, got some triage help from an overworked volunteer - and we waited some more. In the silence of anticipation, and bleeding, we heard a long lecture from our doctors on the failure of our health care system. Our ears burned with the unspoken paean to private health care and a lack of health insurance that often leads to a flooded emergency room. ${ }^{8}$ Silence is also speech since embedded in the silence is public policy. To talk about the wait is to awaken the congealed beliefs about health care in our country and to have a political debate 
about what appears to be simply about the techniques of health care, or the work that a doctor does. Even doctors impose the political opinions that are ingrained in our systems.

Impose is a strong word. The statement from Students for Academic Freedom suggests that teachers force their students to adhere to certain political positions. Given that teachers hold the cards, to enunciate their views on something extraneous to the topic at hand either silences students who do not agree or else makes them pretend to believe the teacher to get a good grade. So if a teacher makes a critical remark about the Iraq war in a class on Dickens, it would make the atmosphere unbearable for a student who favors the war and will make that student lose concentration on the matter at hand. For those of us who believe in the problem of hate speech, this is not a problem to scoff at. ${ }^{9}$ If a conservative student feels assaulted in a classroom where the person in power belittles him or her, then that student has a point. Those of us on the Left engage conservatism and the radical fanaticism of the Right not to demean those who adopt such views, but to challenge them and to offer space for a discussion of issues based on a wide variety of approaches. ${ }^{10}$ For every anecdote of a dogmatic leftist there is one for a dogmatic rightist. I believe that the classroom must enable students to hold a dialogue, to teach students to argue, rather than to learn my own positions by rote (better to teach someone how to fish than to give them one, right?).

Where I have taught, students with liberal or left-leaning views often feel that their professors of the Right or thereabouts afford them no dignity, indeed mock them. ${ }^{11}$ In economics or political science courses, students who raise questions about free trade or about the political duopoly that rules Washington frequently receive the smirk of liberalism. Stanley Fish rightly notes, "The left may have won the curricular battle, but the right won the public-relations war," in other words, the Right has been able to define the academy, wrongly, as the "hotbed of radicalism and pedagogical irresponsibility."12 My own hunch is that the problem of academic arrogance is not ideological but institutional: too many of our colleagues in the academy have an arrogant and haughty attitude to their students, and this should be the issue, not the politics of the professor in question.

The demand that teachers only teach what they are specialists in is a demand made not only by the radical Right but also by the neoliberal center. In 1994, the Council for Aid in Education (CAE) set up the Commission on National Investment in Higher Education. ${ }^{13}$ A year later, the commission's chair, J. L. Dionne, ${ }^{14}$ told a Senate subcommittee on education that the only way to save U.S. education is to "re-engineer to improve productivity and quality, and reduce costs. We need to foster re-engineering of the higher education system, just as we have done in the private sector, to maintain competitiveness." 15 The commission's report, Breaking the Social Contract: The Fiscal Crisis in U.S. Higher Education, appeared in 1997 and offered stringent means to reconstruct the university system. It called on col- 
leges to "restructure and streamline" departments so that "marginal activities" can be reduced or eliminated, and that certain resources can be shared via consortium arrangements. ${ }^{16} \mathrm{CAE}$, at the forefront in education privatization, had not said anything new: since 1975, part-time faculty increased by 97 percent, while full-time faculty grew by only 25 percent across U.S. colleges, and those in full-time positions held mainly nontenure contracts (these increased by 88 percent between 1975 and 1994). ${ }^{17}$ Of these nontenure part-time positions, most are created for and held by women. ${ }^{18}$ These teachers now have to quit their "marginal activities" and get down to the business of teaching more than a full load of information delivery and avoid the more time-consuming effort of critical engagement, all this without substantial support from a defunded system. Overworked teachers are now under pressure to stick to the facts and not talk politics: to be technocrats who live in a world where history has ended, where debate is inconsequential.

The assault on teachers is not simply about academic freedom or, as we will see below, the need for experts to help the U.S. ruling class fight its war on terror. It is part and parcel of the attempt by ruling elites to maintain their authority in a structurally adjusted system: as young people enter a world of either unemployment or McJobs, they are mobilized to maintain faith in the system through patriotism, or a cruel cultural nationalism. ${ }^{19}$ The demand that teachers must stick to the facts is not a neutral approach to academic freedom, but it is a conservative way to say that we should not challenge the unspoken assumptions of the system. Academic freedom, for Horowitz, is not a genuine diversity of opinion and debate but a demand for a more conservative university. Critics like Horowitz concede that higher education provides a space for discussion of the inequities in our world. However, rather than see this discussion as a charter for liberal education and the production of an informed and critical citizenry (writ large), they wish to reduce such a discussion to partisan warfare. If criticism of the system is reduced from the production of citizens to left-wing (or even Democratic Party) propaganda, then it becomes fair game to call for balance, or else to stop such criticism in the first place. We either have the demand to silence liberal and Left scholars or else to hire more conservative scholars. ${ }^{20}$ The point of higher education for people like Horowitz is to conserve the status quo, not to probe it and therefore increase one's stakes in its transformation, or even, after consideration, its maintenance. Without an interrogation of the structures of our world, how would young people have a stake in them?

\section{The Responsibility of the Intellectuals to the State}

In virtually every discipline of social study the dominant academic doctrines conform to the categories of a racial Marxism in which a dominant (white) race and a dominant (male) gender rule as masters over every other. These disciplines include "whiteness studies," "critical race studies," "postcolonial studies," "women's studies” and various "postmodern” perspectives. Through 
prisms like these the American past and present can look very grim to undergraduates innocent of the historical record.

—David Horowitz, Uncivil Wars

In October 2003, as Horowitz's Academic Bill of Rights entered my horizon, so did another Congressional initiative. The House of Representatives passed HR 3077 to create an International Education Advisory Board made up of members of the Department of Defense, the National Security Agency, and the Department of Homeland Security "to increase accountability by providing advice, counsel, and recommendations to Congress on international education issues for higher education." In other words, the bill would allow the government to demand that students who receive aid and study the world enter a war corps to provide the translators and intelligence analysts who will shore up the evangelical imperialism of our times.

Immense pressure from left-leaning teachers, and from Senators Edward Kennedy and Hillary Clinton, killed the measure in the Senate Subcommittee on Education. But this is the bill that will not die, and it reappeared in 2005 as HR 509 (International Studies in Higher Education Act). By all accounts, the strengthened Republican representatives and senators will push hard for its passage, and it is unclear that the Democratic minority will be willing to put itself forward for this fight among the many that face it this season.

The intellectual brainchild of these efforts is Stanley Kurtz, a fellow of the conservative Hudson Institute and a Horowitz booster. ${ }^{21}$ On June 19, 2003, Kurtz sat before the House Subcommittee on Select Education to speak at a hearing on international programs in higher education and questions about bias. Kurtz said, "[Edward] Said equated professors who support American foreign policy with the nineteenth century European intellectuals who propped up racist colonial empires. The core premise of post-colonial theory is that it is immoral for a scholar to put his knowledge of foreign languages and culture at the service of American power."22 Instead, Kurtz suggested, the government must oversee the funds given to universities for the study of the rest of the world, not only to draw scholars to work for the government but, along the grain of Horowitz's analysis, to make scholars offer a positive spin to U.S. history and foreign policy (or to paint a cheerful picture of U.S. interventions abroad).

Kurtz's testimony came as U.S. forces began to confront a resolute and widely dispersed resistance in Iraq. President George W. Bush had already declared the end of combat, but this soon turned out to be a false claim. Academics had already entered the debate on two different fronts-first, as boosters of the need for the U.S. state to embrace its genuine role as imperialist, and second, as translators and interpreters for the endless surveillance of the world and to assist the military in its combat mission. On the first score, both liberal historians and think-tank intellectuals echoed Rudyard Kipling’s 1899 exhortation, “Take Up the White Man's 
Burden."23 Niall Ferguson of the well-named Stern School of Business at New York University (before he moved to Harvard) evoked Kipling's poem, and then wistfully wrote,

No one would dare use such politically incorrect language today. The reality is nevertheless that the United States has_-whether it admits it or not—-taken up some kind of global burden, just as Kipling urged. It considers itself responsible not just for waging a war against terrorism and rogue states, but also for spreading the benefits of capitalism and democracy overseas. And just like the British Empire before it, the American Empire unfailingly acts in the name of liberty, even when its own self-interest is manifestly uppermost. ${ }^{24}$

Academics who criticized the war did not find such spaces to lodge their informed judgment, and indeed many were marked as unpatriotic or even traitors. It was in this context, where criticism of the war on the planet might be considered seditious, that Kurtz marched down to Washington. Ferguson had already begun to point out that the only effective empire would occur when informed administrators (who knew the languages) lived in the colonies and ruled them not by remote control but by direct involvement. Since this is far removed from the culture of U.S. domination, where we prefer to subcontract our domination to loyal others, there was no immediate danger that we in the academy would have to reorganize ourselves into a training ground for colonial administrators. Vocational education for imperialists did not rise on the agenda. Rather, the spirit of what Ferguson said had an impact: now students must be trained to appreciate the burdens borne by the United States to spread "the benefits of capitalism and democracy overseas" and to dismiss (or crush) all those who oppose this agenda. The academy, too, must do its work in the GWOT, just as the U.S. troops are doing their service to the nation on the battlefields that we have created.

Kurtz's view of the academy is similar to Horowitz's: the academy is a hive of leftists who control its every aspect. If this is a gross exaggeration in most spheres, in area studies it is true that the Left and radical democrats have had a powerful impact in its reformation since the 1960s. I want to offer a synoptic history of that reformation in order to suggest that what Kurtz proposes is not a break from government policy, but rather a reaction to the break made by many scholars within area studies from the goals of imperialism.

There was no room in the early U.S. academy for anything but disdain for the rest of the contemporary world. Some scholars wrote with admiration for the distant past of some of the achievements of the ancient civilizations of the darker nations, but nothing of value could be seen in contemporary Asia, Africa, and Latin America. In its infancy, the church and Washington held sway over area studies, even though most of its experts worked within the established departments. ${ }^{25}$ Toward the end of Orientalism, Edward Said noted that in Middle East studies, the U.S. academy had 
taken over the orientalist mantle from the Europeans after World War II, and the "area specialist" now lays "claim to regional expertise, which is put at the service of government or business or both." 26 Indeed, with U.S. domination of the world in the late 1940s, the question of knowledge held center stage for many who knew that you must rule by guns and words. In 1951, a Social Science Research Council (SSRC) report regretted the "woeful lack of area experts, however defined," and it argued that the best thing for U.S. domination of the world was "the launching of scores of area programs." In a moment of candor, the report authored by the University of Michigan East Asia scholar Robert Hall noted, "We must know if we are to survive." 27 Area studies received a major boost from the U.S. government in 1958, with the passage of the National Defense Education Act (NDEA). Title VI of the NDEA ("Language Development") funded several area studies centers. The Fulbright-Hays Act (Mutual Education and Cultural Exchange Act) of 1961 further pushed the government to fund education in foreign languages and in area studies.

Before area studies could get off the ground, the U.S. academy felt a seismic shock from the campus struggles during the Vietnam War and the uprisings of students of color (notably, the frequently repeated Third World strike). Area studies had to be rethought. As Said notes in Orientalism, "The Committee of Concerned Asia Scholars (who are primarily American) led a revolution during the 196os in the ranks of East Asia specialists; the African studies specialists were similarly challenged by revisionists; so too were other Third World area specialists." 28 In 1964, the U.S. government launched Project Camelot to finance scholars who would study the "social processes which must be understood in order to deal effectively with problems of insurgency." 29 When the anthropologist Eric Wolf and others revealed the scheme, scholars of Latin America and elsewhere rebelled against governmental intrusion. ${ }^{30}$ The Association of Concerned African Scholars emerged in 1977 to ensure that the famine-failure story of Africa would not disguise continued imperial interests in the raw materials and markets of the continent, and that the U.S. collaboration with South Africa not be mirrored in the classroom. Said regrets that Middle East studies did not have a similar challenge. ${ }^{31}$

With the fall of the Soviet Union, the U.S government has attempted to retake area studies from those of us who have a prejudice toward tolerance, negotiation, and empathy. Foundations wanted colleges to rethink area studies and move toward internationalization, although all such initiatives did not come with humanitarian aims since the motives of profit and power drove many of them. ${ }^{32}$ The most impressive salvo came in 1991 from Senator David Boren's National Security Act, which wanted to "produce an increased pool of applicants for work in the departments and agencies of the U.S. government with national security responsibilities."33 The bill would have become law but for Newt Gingrich's campaign to cut government spending. Kurtz now uses $9 / 11$ to recycle Boren’s failed bill.

"The events and aftermath of September 11, 2001, have underscored the 
need for the Nation to strengthen and enhance American knowledge of international relations, world regions and foreign languages," notes one draft of HR 509 . "Homeland security and effective United States engagement abroad depend upon an increased number of Americans who have received such training and are willing to serve their nation." 34 Not only does the government want our new imperialists to become security experts, but because of the nature of neoliberal imperialism, the government will join with corporations and with the universities to create Centers for International Business Education. None of this should be a surprise because the global war on terror has already drawn neoliberal economic policies into the framework of national security: the president's 2002 national security strategy document noted, "A strong world economy enhances our national security by advancing prosperity and freedom in the rest of the world," and, on July 28, 2005, the president's press secretary defended the Central American Free Trade Agreement on these lines: "This goes right to our own national security. This is an agreement that will help extend peace and prosperity throughout the Western Hemisphere." Teachers must both stick to the facts and teach for the state. ${ }^{35}$

\section{Campus Fear Factor}

The Global War against Teachers, the Academic Bill of Rights, and HR 509 have produced fear on the campus that we are to be overrun by a thought police, that our administrators will have the fear of lawsuits and adverse publicity to contend with if they do not chide us to stick to the facts and to forgo any critical dialogue on the state of our world. Fear is corrosive: it eats into the institution and, even if there is no substantial change to satisfy the partisans of the Right, it emboldens the conservatives and the radical Right to make other demands on us. As Stanley Fish writes in his criticism of Horowitz,

It is obvious that for Horowitz these are debating points designed to hoist the Left by its own petard; but the trouble with debating points is that they can't be kept in bounds. Someone is going to take them seriously and advocate actions that Horowitz would probably not endorse. Someone is going to say, let's monitor those lefty professors and keep tabs on what they're saying; and while we're at it, let's withhold federal funds from programs that do not display "ideological balance" ("balance" is also an unworthy academic goal); and let's demand that academic institutions demonstrate a commitment to hiring conservatives; and let's make sure that the material our students read is pro-American and free of the taint of relativism; and let's publish the names of those who do not comply. 36

This assault and the fear that it will engender has nothing to offer the genuine problems of our academy, such as, why do our students feel bored by the education we offer, or how do we teach students who must enter a world with few decent jobs (or where most jobs are now McJobs, even those that pay a high salary), or indeed, what 
do we say to our students who are conscripted by the poverty draft into a war that they know nothing about? Fear does not help us formulate and answer these questions, these genuine problems of the bulk of our students.

\section{Notes}

Thanks to all those who joined together to stop HR 3077 , and to those who will join us now to stop HR 509. I am particularly grateful to John Wilmerding of Campaign/Coalition for EquityRestorative Justice (CERJ), the anthropology students at Cornell, the staff at Senator Kennedy's office, Lisa Armstrong and Amrita Basu for their conference at Smith College (and Joy James for our conversation there and elsewhere), and to many others.

1. The Pentagon uses the acronym GWOT for its global war against terrorism, so I have used GWOT2 for Global War against Teachers. But since the U.S. education secretary Roderick Paige called the 2.7 million member National Educators Association (the country's largest teachers' union) "a terrorist organization," it might not be inappropriate for Horowitz's actions to be part of GWOT itself. For Paige, see Amy Goldstein, "Paige Calls NEA a 'Terrorist' Group," Washington Post, February 24, 2004.

2. David Horowitz, Uncivil Wars: The Controversy over Reparations for Slavery (San Francisco: Encounter Books, 2002).

3. Amanda Paulson, "A Bill to Protect Campus Conservatives?" Christian Science Monitor, January 8, 2004; and John Sanko, "Colorado Academic Showdown," Rocky Mountain News, September 2, 2004. The bill can be viewed at a Web site that collects many of the central texts of this movement, the Students for Academic Freedom, www.studentsforacademicfreedom.org (accessed October 1, 2004).

4. Well, Stanley Fish. He maintains that the academy is a space for "teaching and research," and not for the development of "creative individuals and productive citizens." Stanley Fish, "Intellectual Diversity: The Trojan Horse of a Dark Design," Chronicle of Higher Education, February 13, 2004.

5. Horowitz's agenda is similar to the assault waged in India, the UK, and elsewhere against teachers' unions and the broad liberal and left-leaning philosophical bent of much of the curriculum in a world that has benefited from socialism's goals (after all, public education is a child of socialism).

6. Brown Daily Herald, November 18, 2003. Horowitz's controversy at Brown is now well known. He goes over his side of the story in Uncivil Wars, 54-69. For a more balanced and less caustic approach, see Norman Boucher, "The War Over Words," Brown Alumni Magazine, May-June 2001, www.brownalumnimagazine.com/storyDetail.cfm?ID=169.

7. Here is Horowitz himself: "We do not go to our doctors' offices and expect to see partisan propaganda posted on the doors, or go to hospital operating rooms and expect to hear political lectures from our surgeons. The same should be true of our classrooms and professors, yet it is not.” David Horowitz, "In Defense of Intellectual Diversity," Chronicle of Higher Education, February 10, 2004, www.frontpagemag.org/articles/ReadArticle .asp?ID=12116.

8. American Council of Physicians/American Society of Internal Medicine, No Health Insurance? It's Enough to Make You Sick (2000), www.acponline.org/uninsured/ lack-contents.htm (accessed October 3, 2004).

9. Mari Matsuda, Charles Lawrence III, Richard Delgado, and Kimberlé Crenshaw, Words that Wound: Critical Race Theory, Assaultive Speech, and the First Amendment (Boulder, CO: Westview, 1993). 
10. To make such room for a discussion available to students does not mean that the classroom becomes a "neutral, value-free" space. Moishe Postone raises some important issues with Jürgen Habermas's The Theory of Communicative Action (1981) in "History and Critical Social Theory," Contemporary Sociology 19 (1990): 170-76.

11. Horowitz's various organizations and publications rely on anecdotal evidence to base their supposition that the campus is hostile to conservative students. There is no systematic, survey-based study that affirms the Horowitz position. The study, Political Bias in the Administrations and Faculties of Thirty-two Elite Colleges and Universities, authored by Horowitz and Eli Lehrer, is based on a comparison between lists of faculty and administration with voting records. The fact that Democrats outrank Republicans at these institutions by ten to one leads to the conclusion that the academy does not sufficiently teach conservative thought. The methodology is deeply flawed because it makes claims about the general campus culture based on a study of voting records and not on the basis of the campus culture itself — by surveys, for instance, that look at student satisfaction with intellectual and political diversity on campus. Study available at www.frontpagemag.com/ Content/read.asp?ID=55 (accessed December 16, 2005).

12. Fish, "Intellectual Diversity."

13. CAE is a subsidiary of that old cold warrior, the RAND corporation.

14. Dionne was the CEO of McGraw-Hill, an interested party in the deliberations: they produce the textbooks for McEducation.

15. Statement by Joseph L. Dionne, U.S. Senate Subcommittee on Education, Arts, and Humanities of the Committee on Labor and Human Resources, February 2, 1995.

16. Jeri O'Donnell, ed., Breaking the Social Contract: The Fiscal Crisis in U.S. Higher Education (Santa Monica, CA: RAND Corporation, 1997).

17. Linda Ray Pratt, "Disposable Faculty: Part-Time Exploitation as Management Strategy," in Will Teach for Food: Academic Labor in Crisis, ed. Cary Nelson (Minneapolis: University of Minnesota Press, 1997), 264-77; and Karen Thompson, "Alchemy in the Academy: Moving Part-Time Faculty from Piecework to Parity," in Nelson, Will Teach for Food, 278-9o. The increase in tuition, as many studies show, has gone toward a bloated administration, a building spurt, and toward a technological makeover on campus, another way to increase productivity without bodies. See Raymond Garcia, "Back to the Middle Ages: The Rise of the Lumpen Teacher," Counterpunch, May 1-15, 1998; and Ellen Schrecker, "Will Technology Make Academic Freedom Obsolete," in Nelson, Will Teach for Food.

18. James D. Sullivan, "The Scarlet L: Gender and Status in the Academe," in Nelson, Will Teach for Food, 254-63; and Margie Burns, "Service Courses: Doing Women a Disservice," Academe, May-June 1993.

19. I lay this out in the introduction to my Keeping Up with the Dow Joneses: Debt, Prison, Workfare (Boston: South End Press, 2003).

20. So when Horowitz says that he is in favor of intellectual diversity rather than political diversity, it is odd that his main claim is that there are more Democrats on the campus than Republicans-this is about political affiliation in the ballot box, not about intellectual diversity. See Sara Hebel, "Patrolling Professors' Politics," Chronicle of Higher Education, February 13, 2004, www.chronicle.com/free/v5o/i23/23ao1801.htm. Brett O’Bannon asks why there are fewer conservatives in higher education and offers this answer: "The problem lies, therefore, not with university hiring practices and certainly not with the evil machinations of liberals bent on ruining our youth. In fact, there is no problem here. The absence of larger numbers of conservative faculty members is, to a great extent, explained 
by the very correlation between education and ideology. Other explanations might relate to the different choices that liberals and conservatives, especially those with advanced degrees, make about education, careers and income. Simply put, more conservatives with a bent for higher education are going to have to opt for smaller salaries if their presence in the academy is to grow." Brett O’Bannon, "In Defense of the 'Liberal Professor,'” Indianapolis Star, August 27, 2003.

21. On his fealty to Horowitz's crusade against the campus, see Stanley Kurtz, "Clouded by Bias," National Review, June 5, 2001, www.nationalreview.com/contributors/kurtzo60501 shtml. On his general view that there are too few conservatives and hawks on the college campus, see Kurtz, "Ivy Change," National Review, October 29, 2001, www.nationalreview .com/contributors/kurtz102901.shtml. Here he uses $9 / 11$ to do his work, although he has proposed much of this before 9/11, such as in "Taking Back the Academy," National Review, February 9, 2001, www.nationalreview.com/comment/commento2ogorb.shtml.

22. "Statement of Stanley Kurtz, Research Fellow, Hoover Institution; Contributing Editor, National Review Online. Testimony before the Subcommittee on Select Education, Committee on Education and the Workforce, U.S. House of Representatives, June 19, 2003," edworkforce.house.gov/hearings/108th/sed/titlevi61903/kurtz.htm.

23. Max Boot, former editor of the Wall Street Journal, led the way ("The Case for American Empire," Weekly Standard, October 15, 2001) and stayed ("The Case for Wise Liberal Imperial Rule," Financial Times, July 14, 2004) in the fight to redefine U.S. self-perception of its global role. He made the case in his book Savage Wars of Peace: Small Wars and the American Rise to Power (New York: Basic Books, 2002), whose title is drawn from Kipling's poem. In the Kipling vein came the "fully paid up member of the neo-imperialist gang," Niall Ferguson with his “The Empire Slinks Back," New York Times Magazine, April 27, 2003. By far the doyen of this line of thought, because of his impeccable liberal credentials, is the Carr Professor of Human Rights at Harvard, the Canadian scholar Michael Ignatieff, who put the case before the Iraq war with "Nation-Building Lite," New York Times Magazine, July 28, 2002, and then returned with Kiplingesque flourish in "The American Empire: The Burden," New York Times Magazine, January 5, 2003.

24. Niall Ferguson, Empire: How Britain Made the Modern World (London: Allen Lane, 2003), 369-70. Also see his "The Empire Slinks Back.”

25. Yale's K. S. Latourette founded East Asian studies-his book is History of the Christian Missions in China (New York: Macmillan, 1929); Berkeley's H. E. Bolton pioneered Latin American studies with his The Rim of Christiandom: A Biography of Eusebio Francisco Kino, Pacific Coast Pioneer (New York: Macmillan, 1936); and A. C. Coolidge developed the contours of Slavic studies in The United States as a World Power (New York: Macmillan, 1927).

26. Edward Said, Orientalism (New York: Random House, 1978), 285.

27. Robert Hall, Area Studies: With Special Reference to Their Implications for Research in the Social Sciences (New York: Social Science Research Council, 1951), 2, 22-23. For more, see Wendell C. Bennett, Area Studies in American Universities (New York: Social Science Research Council, 1951), and Robert E. Ward, "The Presidential Address: A Case for Asian Studies," Journal of Asian Studies 32 (1973): 391-403.

28. Said, Orientalism, 301.

29. "Office of the Director of Special Research Operations Office, Document 1, December 4, 1964," in The Rise and Fall of Project Camelot: Studies in the Relationship between Social Sciences and Practical Politics, ed. Irving Horowitz (Cambridge, MA: MIT Press, 1967), 48. 
30. The documents are collected in Horowitz, The Rise and Fall of Project Camelot.

31. "Lamentably, there has been no demonstrable effect-if there has been a challenging gesture at all—made by Islamic or Arab scholars' work disputing the dogmas of Orientalism; an isolated article here or there, while important for its time and place, cannot possibly affect the course of an imposing research consensus maintained by all sorts of agencies, institutions and traditions," Said, Orientalism, 301. Nevertheless, there is now a radical rightist academic militia, much of it provoked by the impact of Said's work, that patrols Middle East studies. Martin Kramer not only produced a book to denounce the field, Ivory Towers on Sand: The Failure of Middle Eastern Studies in America (Washington, DC: Washington Institute for Near Eastern Policy, 2001), but also created an organization called Middle East Forum (directed by Kramer's comrade-in-arms, Daniel Pipes) and a Web site, www.campuswatch.org, to monitor the field.

32. The business implications of internationalization came to the fore in 1990, when the National Governors' Association bemoaned the lack of international education for college graduates in a globalized world. "The best jobs, the largest markets and the greatest profits will flow to the workers and firms that understand the world around them," said the governors. Their analysis of recent history led to the assessment that "a lack of understanding and inability to communicate contributed to such events as the war in Vietnam, the hostage crisis in Iran, the OPEC oil crisis, and the political consequences of the Bhopal industrial disaster." The motives of power and profit are freed of any responsibility for this litany of ills—we are left with E. M. Forster's dictum, "Only Connect," from Howard's End (1910).

33. Bruce Cumings, "Boundary Displacement: Area Studies and International Studies during and after the Cold War," in Universities and Empire: Money and Politics in the Social Sciences during the Cold War, ed. Christopher Simpson (New York: New Press, 1998), 177.

34. International Studies in Higher Education Act of 2005, HR 509, Sec. 2, (a) (4), 109th Cong., 1st sess., thomas.loc.gov/cgi-bin/query/F?c1og:1:/temp/ c1ogHgJLTv:e1288 (accessed December 29, 2005).

35. "National Security Strategy of the United States of America, September 2002, Section VI," www.whitehouse.gov/nsc/nss6.html; and "Press Briefing by Scott McClellan, Office of the Press Secretary, White House, July 28, 2005," www.whitehouse.gov/news/ releases/2005/07/20050728-3.html.

36. Fish, "Intellectual Diversity." All this, indeed, is already the case-www.campuswatch.org is a case in point. 